\title{
The Development of "Chemtective" Game-Based Medium on Chemistry Learning
}

\author{
Atiek Winarti, Febrina R. Tirto, Arini D. Aprilia, Eva Raihana, N. Hidayati \\ Chemistry Education Department, Faculty of Teaching Training and Education \\ Universitas Lambung Mangkurat \\ Banjarmasin, Indonesia \\ atiekwin_kimia@unlam.ac.id
}

\begin{abstract}
The purpose of this study was to develop "Chemtective" as a game-based learning medium which was valid, practical, and effective in improving students' interest and motivation in learning Chemistry. "Chemtective" is a computer game-based medium designed by collaborating "chemistry subject" and "detective stories". The method employed in this study was Research and Development $(R \& D)$. The validity of the medium was evaluated by three media experts. As many as 34 students of SMA Negeri 2 Banjarmasin were selected as the try out subjects. The data of validity, practicality and effectiveness of the medium were collected by using validity sheet, observation sheet, students' responses and students' interest questionnaire. The practicality of the medium was evaluated by three observers and the effectiveness was evidenced by the improvement of students' interest in learning chemistry. The analysis of the data used percentage method. The result showed that "Chemtective" was valid, can practically be implemented, and was effective to improve students' interest in learning chemistry.
\end{abstract}

Keywords-chemtective; game-based medium; students' interest

\section{INTRODUCTION}

Learning is a process of delivering a message from the source to the recipients by using particular media [1]. However, there are several factors that become barriers of this process. One of them is psychological barrier related to interests, attitudes, opinions, beliefs, intelligence, and knowledge. Students who are interested in the lesson, topic, and teacher would have different learning outcomes compared to those who are not interested in it or do not like it.

Reference [2] stated that students' interest and motivation will influence the quality of learning outcomes in particular subject. The more the students' interest is, the more intensive the students' focus. As a result, students learn more actively in gaining achievement. On the contrary, lack of interest and motivation to learn will make students less motivated to be involved in the learning process.

This problem is often encountered in Chemistry subject, one of which is on Periodic Table of Elements (PTE) subject matter. Periodic Table of Elements is one of the essential subject matters in Chemistry. It is generally studied in the beginning of the $10^{\text {th }}$ grade of senior high school to introduce basic chemistry. PTE material consisted of four parts, namely; modern periodic system, development of the basic grouping of elements, periodic properties of the elements, and some classes of elements in the periodic system. A study conducted by [3] showed that PTE is one of the considered difficult subject materials because it consisted of too many memorized materials. Meanwhile, according to [4] PTE is an abstract material, so it requires media as a learning tool. This is compounded by the use of a common lecture method in teaching PTE subject that makes students become quickly bored and not interested in studying. As the impact, the students' learning outcomes are not in line with the expectations.

According to [5], teachers and instructors have a responsibility in designing learning tasks in such a way so that students have the opportunity to gain experience and a sense of personal achievement, as well as awards. The personal satisfaction will increase students' interest and motivation. Reference [6] states that interest can be built by designing the subject matter into a package of interesting information presented in interesting instructional media.

Problems encountered in learning Periodical Table of Elements (PTE) will be resolved by designing an interesting game-based instructional medium. According to the study conducted by [7], game-based instructional medium has a lot of benefits to students, such as facilitating difficult concepts to grasp, increasing the attractiveness of the subject matters, and providing fun learning solutions to solve problems. A study conducted by [8] revealed that students who played gamebased media in learning science demonstrated improvement learning outcomes. Game -based learning also encourages students to explore science concepts.

Therefore, to overcome the lack of interest and motivation of students to PTE material, this study intended to develop "Chemtective"; a game-based instructional medium that is valid, practical, and effective. "Chemtective" is a gamebased medium which is expected to help students to solve problems regarding the difficulties of the PTE material. The game-based learning medium was called "Chemtective", because the game uses chemistry along with detective stories as the background. "Chemtective" contains three basic media elements; sound, images, and text, presented as a game with 
the clear storyline. The use of game-based medium containing detective stories as a background makes "Chemtective" compatible with nearly all the students' learning style, whether visual, audio, kinesthetic, and audio-visual. By using an informal and entertaining game such as "Chemtective", students' interest and motivation to learn PTE material can be increased. Thus, students' achievement will be increased as well.

According to [6], the use of a good game program design improves students' interest and motivation. This idea is reinforced by research conducted by [9] concerning the use of audio-visual media as a teaching tool at schools. The research established that instructional activities using multimedia give the higher learning outcomes than the instructional teaching without media.

\section{METHOD}

The applied method in this study was Research and Development (R \& D) by Borg \& Gall design [10]. The try out of "Chemtective" was conducted at SMAN 2 Banjarmasin. The sample consisted of 34 of $10^{\text {th }}$ grade students. The validity of the medium was evaluated by three experts. The data were collected by using validation sheet, observation sheet, and students' interest questionnaire. The validity of the medium is determined by using the validity criteria $1<\mathrm{M}<2$ (poor), $2 \leq \mathrm{M}$ $<3$ (invalid), $3 \leq \mathrm{M}<4$ (valid), and $4 \leq \mathrm{M}<5$ (very valid). The practicality and effectiveness of the medium were analyzed by using percentage technique. This medium is categorized as practical and effective if the percentage result of students and teacher activities when applying the medium, students' response, and students' interest to the medium are more than $40 \%$.

\section{RESULTS AND DISCUSSION}

\section{A. Results}

\section{1) Validity}

The validity of "Chemtective" was evaluated by assessing the quality of the content, language, and medium display using validation sheet. Questions about the content consisted of eight aspects, the language consisted of three aspects, and the medium display consisted of five aspects. The result of validation conducted by three experts can be concluded as follows.

TABLE I. VALIDATION RESULT OF "CHEMTECTIVE"

\begin{tabular}{|l|c|c|c|c|c|}
\hline \multirow{2}{*}{ Aspects } & \multicolumn{3}{|c|}{ Score of Validator } & \multicolumn{2}{c|}{ Mean } \\
\cline { 2 - 6 } & I & II & III & Score & Aspect \\
\hline Content & 32 & 31 & 30 & 31 & 3.9 \\
\hline Language & 12 & 11 & 9 & 11 & 3.6 \\
\hline Display & 21 & 18 & 19 & 19.3 & 3.9 \\
\hline Means & & & & & 3.8 \\
\hline
\end{tabular}

The means of the medium validity scored by validators was 3.8 or valid. Based on the validation of the three experts, it can be concluded that "Chemtective" is worth to be used with minimal revision. In general, Chemtective has been good in terms of content and display. Of the three factors, quality of the content and medium display gained the highest score, while language gained the lowest score and should be revised. Typeface, the use of color, and the story still need to be improved in order to look more attractive.

The quality of the content and medium display received high score from all validators. The content of the medium and the medium elements such as pictures and text were attractive. Indeed, "Chemtective" contains various interesting cases which are challenging to be solved, such as theft, kidnapping, and bombing. In order to get the clues for solving the cases, the player must answer the questions about chemical elements. The difficulty level of the questions is related to the number and the importance of the clues. Those who succeed to answer difficult questions will get more clues to crack the case. Therefore, the attractiveness of the game content lies on the combination of the chemical concept mastery, the setting strategy, and the cooperation in solving problems. It is relevant to [11] that the interesting games used in learning is a game designed by combining aspects of cognitive, affective, motivational and sociocultural.

\section{2) Practicality}

In the trial step, the practicality of "Chemtective" was indicated by students' activities and interaction between students or teachers and the medium during the lesson. Observation of students and teacher activities was conducted by five observers during the lesson. "Chemtective" was piloted on two lessons, lesson 1 was conducted before revising and lesson 2 was conducted after revising the medium. Based on the observation result, the practicality of the medium was explained as follows.

TABLE II. THE OBSERVATION RESULT OF THE MEDIUM APPLICATION

\begin{tabular}{|c|c|c|c|}
\hline \multirow{2}{*}{ No. } & \multirow{2}{*}{ Indicators } & \multicolumn{2}{|c|}{ Total score } \\
\hline & & Lesson 1 & Lesson 2 \\
\hline 1 & $\begin{array}{l}\text { Students look happy when playing the } \\
\text { game. }\end{array}$ & 26 & 28 \\
\hline 2 & $\begin{array}{l}\text { The rule of the game is clearly explained, } \\
\text { showing by no questions asked by students } \\
\text { when playing the game. }\end{array}$ & 27 & 27 \\
\hline 3 & The games are easily to be applied. & 28 & 28 \\
\hline 4 & $\begin{array}{l}\text { Chemtective takes an important role in } \\
\text { learning process. }\end{array}$ & 26 & 27 \\
\hline 5 & Students can quickly answer the questions. & 19 & 26 \\
\hline 6 & $\begin{array}{l}\text { The medium helps students' to practice } \\
\text { solving the problems. }\end{array}$ & 27 & 27 \\
\hline 7 & $\begin{array}{l}\text { The use of chemtective improves students' } \\
\text { activity. }\end{array}$ & 26 & 27 \\
\hline 8 & $\begin{array}{l}\text { The use of the medium helps teachers to } \\
\text { efficiently manage the time. }\end{array}$ & 20 & 26 \\
\hline 9 & $\begin{array}{l}\text { The set of chemtective engaged students } \\
\text { attention. }\end{array}$ & 28 & 28 \\
\hline 10 & $\begin{array}{l}\text { The medium is suitable with the PTE } \\
\text { material. }\end{array}$ & 29 & 29 \\
\hline & Amount & \multicolumn{2}{|c|}{256} \\
\hline & Percentage & \multicolumn{2}{|c|}{$73 \%$} \\
\hline
\end{tabular}

The data on Table II above shows that the practicality of the medium in the first trial was $73 \%$. It means that this medium can be categorized as practical. Yet, there are several 
factors of the medium that need to be improved for example the time allocation. Based on observation result number 5 , it was found that answering question activity takes much time. Students can not answer the questions quickly. That is why in the second trial, time for answering questions activity was extended. It appears that in the second trial the practicality of the medium slightly increased. Thus, from both trials it can be concluded that "Chemtective" is easily used and understood.

\section{3) Effectiveness}

The effectiveness of "Chemtective" was indicated by students' responses toward the medium and the capability of "chemtective" to improve students' interest in learning chemistry. Students' responses were selected by giving questionnaire to five students. The students evaluated the use of language and the medium display viewed from the color, font type and size, and also the illustration. Students' responses of "Chemtective" can be seen as follows:

TABLE III. VALIDITY COEFFICIENT AND AVERAGE SCORE OF THE MEDIUM APPLICABILITY

\begin{tabular}{|c|c|c|c|c|c|c|}
\hline \multirow{2}{*}{ No. } & \multirow{2}{*}{ Indicators } & \multicolumn{5}{|c|}{ Score } \\
\hline & & 1 & 2 & 3 & 4 & 5 \\
\hline \multicolumn{7}{|c|}{ A. Language } \\
\hline 1 & The words are clear and easy to understand. & & & & 2 & 3 \\
\hline 2 & $\begin{array}{l}\text { It uses correct grammar of Bahasa } \\
\text { Indonesia. }\end{array}$ & & & & 4 & 1 \\
\hline 3 & It uses effective and efficient words. & & & & 3 & 2 \\
\hline \multicolumn{7}{|c|}{$\begin{array}{r}\text { B. Medium Display } \\
\end{array}$} \\
\hline 4 & The color is attractive. & & & & 1 & 4 \\
\hline 5 & $\begin{array}{l}\text { It uses appropriate lay out, font type and } \\
\text { size. }\end{array}$ & & & 1 & 2 & 2 \\
\hline 6 & $\begin{array}{l}\text { It uses attractive illustration, graphic, } \\
\text { figures, and pictures. }\end{array}$ & & & & & 5 \\
\hline 7 & It uses attractive and varies design. & & & & 1 & 4 \\
\hline 8 & $\begin{array}{l}\text { It uses illustration, graphic, figures, and } \\
\text { pictures that do not contain elements of } \\
\text { violence, pornography and SARA }\end{array}$ & & & & 2 & 3 \\
\hline & Amount & \multicolumn{5}{|c|}{183} \\
\hline & Percentage & \multicolumn{5}{|c|}{$92 \%$} \\
\hline
\end{tabular}

In the preliminary assessment, the obtained of average percentage of medium practicality was $92 \%$. In other words, the language of "Chemtective" was easily understood and the medium display was attractive. The clarity of the language got a lower response (88\%) than the medium display (94\%). It means that the display becomes the main interest of the media. Students also gave some suggestions about the time allocation for finishing the questions. Some questions seemed difficult and consume a lot of time to answer. So, the time should be extended in order to give students more opportunity to finish the problems.

After revising the medium of this study, in the second trial, "Chemtective" was tested to 34 of $10^{\text {th }}$ grade students. Students' motivation was measured by giving questionnaire fulfilled by all students. In the questionnaire, the students expressed their interest toward "Chemtective" and to what extent they were motivated in learning chemistry using "Chemtective" medium. Students' interest toward
"Chemtective" in the second trial is shown by the following table.

TABLE IV. STUDENTS INTEREST TOWARD “CHEMTECTIVE”

\begin{tabular}{|c|l|c|c|c|c|c|}
\hline \multirow{2}{*}{ No } & \multicolumn{1}{|c|}{ Statements } & \multicolumn{5}{|c|}{ Scores } \\
\cline { 3 - 7 } & \multicolumn{1}{|c|}{$\begin{array}{c}\text { Learning PTE using Chemtective } \\
\text { makes me easier to understand } \\
\text { chemistry. }\end{array}$} & & 2 & 4 & 15 & 13 \\
\hline 2 & $\begin{array}{l}\text { Exercises in "Chemtective" really } \\
\text { help me to better understand the } \\
\text { chemistry concepts. }\end{array}$ & & 1 & 4 & 22 & 7 \\
\hline 3 & $\begin{array}{l}\text { Chemtective medium motivates } \\
\text { me to learn chemistry. }\end{array}$ & & & 8 & 23 & 3 \\
\hline 4 & $\begin{array}{l}\text { Chemtective medium makes } \\
\text { learning chemistry more } \\
\text { attractive. }\end{array}$ & & & 3 & 18 & 13 \\
\hline 5 & $\begin{array}{l}\text { Chemtective medium makes me } \\
\text { easier to follow Chemistry lesson. }\end{array}$ & & 2 & 5 & 21 & 6 \\
\hline 6 & $\begin{array}{l}\text { The use of Chemtective in } \\
\text { learning chemistry is not } \\
\text { confusing. }\end{array}$ & & & 10 & 23 & 1 \\
\hline 7 & $\begin{array}{l}\text { Chemtective makes me feel } \\
\text { happy while learning Chemistry. }\end{array}$ & & 2 & 5 & 20 & 7 \\
\hline 8 & $\begin{array}{l}\text { Chemtective makes me more } \\
\text { excited to learn Chemistry than } \\
\text { ever. }\end{array}$ & & 1 & 6 & 20 & 7 \\
\hline 9 & $\begin{array}{l}\text { Chemtective makes me more } \\
\text { confident in learning Chemistry. }\end{array}$ & & 5 & 8 & 17 & 4 \\
\hline 10 & $\begin{array}{l}\text { Chemtective helps me remember } \\
\text { the lesson longer. }\end{array}$ & 1 & 16 & 14 & 3 \\
\hline & \multicolumn{3}{|c|}{ Percentage } & $82 \%$ & \\
\hline
\end{tabular}

Table IV shows that, in general, students' interest toward "Chemtective" is positive. Statement number 4 "Chemtective medium makes learning chemistry more attractive" received the most positive feedback than any other statements. Instead, statement number 10 "Chemtective helps me remember the lesson longer" obtain the fewest positive response. Even though only $50 \%$ students who agreed with this statement, most students agreed that "Chemtective" helps them to better understand of chemistry concepts. From the students' responses and students' interest in the table above, it can be concluded that Chemtective is effective. Chemtective is also attractive and helps students learning chemistry better because it motivates students to enjoy chemistry.

\section{B. Discussion}

Chemtective is a game-based learning multimedium in which students solve mysterious cases by applying the knowledge of Periodical Table of Elements (PTE). Any clues to solve the cases such as the theft, the kidnap or the bombing were obtained by answering questions about the PTE. During chemistry lesson using "Chemtective", the students seemed enjoy it. They were also engaged to the lesson until the class finished. Students engagement to the lesson was due to "Chemtective" application as stated by [12]. As many as 1.2 billion people tend to play games, that is why a game like "Chemtective" gained positive perception from most students and showed high practicality. Besides having the challenging cases, the attractiveness of "Chemtective" is also caused by the presence of exciting game play elements such as pictures, 
color, figures and storyline. Data in Table 3 show that, in general, students were interested on "Chemtective" because of the use interesting media elements such as illustrations, graphics, pictures and color. According to [13], besides engaging motivation, the use of moving images, color and illustration that form certain patterns also have a great influence in the process of entering information. The more visuals that were used, the higher the quality of learning is. The use of this visual medium should have an effect on the ability to remember.

Indicators of medium practicality were evident from the students' responses when interacting with the medium during the lesson. Data on Table 2 show that students seem cheerful when playing the game. Students also found it easy to play, so "Chemtective" is able to engage students' attention. In general, "Chemtective" is very suitable for teaching Periodical Tabel of Elements material.

Students positive response to "Chemtective" that was found in this research was similar to the study conducted by [13]. In this previous study, the respondents consisting of 72 high school students had positive perceptions toward the game-based instruction and its learning efficiency. They also felt the game-based instruction was much more interesting than traditional didactic lectures.

The attractiveness of the game including images, sounds and storyline puzzles makes students are motivated to learn. It is able to attract students attention during the lesson as well. Indeed, the usage of games game-based learning is an effective instructional strategy for engaging learning and motivating students [14].

\section{CONCLUSION}

Based on the findings of this study, it can be concluded that "Chemtective", the game-based instructional medium developed in this study, was valid, practical, and effective to improve students interest in learning Chemistry particularly on Periodic Table of Elements (PTE) subject matter.

\section{REFERENCES}

[1] A. S. Sadiman, "Media Pendidikan (Pengertian, Pengembangan, Dan Pemanfaatannya)," Jakarta: PT Raja Grafindo Persada., 2003.

[2] M. Syah, "Psikologi Belajar", Jakarta : PT Raja Grafindo Persada., 2012.

[3] W. A. Murtandho, "Pengaruh Pembelajaran Learning Cycle Pada Materi Sistem Periodik Unsur Terhadap Motivasi Dan Hasil Belajar Siswa," Fakultas Keguruan dan Ilmu Pendidikan, Universitas Tanjungpura., Pontianak, 2014.

[4] A. Nadhifah, "Pengembangan Lanjutan Pproduk Kartu SPU untuk Peningkatan Motivasi Dan Prestasi Belajar Kimia Kelas X," Fakultas Sains dan Teknologi, Universitas Islam Negeri Sunan Kalijaga., Yogyakarta, 2012.

[5] I. K. Davies, "Pengelolaan Belajar," Jakarta, Jakarta: CV. Rajawali, 1991.

[6] A. Arsyad, "Media Membelajaran.," Jakarta: PT RajaGrafindo Persada., 2011.

[7] N. B. Sardone and R. Devlin-Scherer, "Teacher candidates' views of digital games as learning devices," Issues in Teacher Education , vol. 18, no. 2, pp. 47-67, 2009.

[8] C. H. Chen, K. C. Wang, Y. H. Lin, "The comparison of solitary and collaborative modes of game-based learning on students' science learning and motivation," Educational Technology \& Society, vol. 18, no. 2, pp. 237-248, 2015

[9] W. Schramm, Media Besar, Media Kecil. Terjemahan Drs. Agafur, M.Sc., Semarang: IKIP Semarang Press, 1984.

[10] M. D Gall; R. B. Walter, P. G. Joyce, "Educational Research: An Introduction, 8th Edition," New Jersey: Pearson, 2007.

[11] J. L. Plass, B. D. Homer, C. K. Kinzer, "Foundations of game-based learning," Educational Psychologist, vol. 50, no. 4, pp. 258-283, 2015.

[12] T. Soper, "Greek wire study: 1.2 billion people are playing games worldwide; 700M of them are online," 25 November 2013. [Online]. Available: http://www.geekwire.com/2013/gaming-report-12-billionpeople-playing-games-worldwide/. [Accessed 10 April 2017].

[13] T. F. Su, M. T. Cheng, S. H. Lin, "Investigating the effectiveness of an educational card game for learning how human immunology is regulated," CBE - Life Sciences Education, vol. 13, no. 3, pp. 504-515, 2014.

[14] E. Jensen, "Brain Based Leaning," California: Corwin Press A Sage Publication Company, 2008.

[15] R. Tham and L. Tham, "The effectiveness of game-based learning as an instructional strategy to engage students in higher education in singapore," International Journal on E-Learning, vol. 13, no. 4, pp. 483496, 2014. 